\title{
Media Pembelajaran Matematika SMP Berbasis Android Berorientasi UoS untuk Meningkatkan Hasil Belajar Siswa
}

\author{
Ahmad Aunur Rohman ${ }^{1 *}$, Ismail M. ${ }^{2}$, Emy Siswanah ${ }^{3}$ \\ ${ }^{1,2,3}$ Pendidikan Matematika UIN Walisongo Semarang \\ "ahmad.aunurrohman@walisongo.ac.id
}

\begin{abstract}
ABSTRAK
Terdapat keterbatasan sumber belajar siswa dan sarana pembelajaran yang terdapat di SMP Negeri 1 Kendal. Penelitian ini dimaksudkan untuk menjawab permasalahan tersebut, dengan tujuan untuk mengetahui apakah media pembelajaran matematika SMP berbasis android berorientasi $U o S$ pada materi lingkaran dapat meningkatkan hasil belajar siswa. Jenis penelitian ini adalah kuantitatif. Penentuan sampel menggunakan teknik purposive sampling dengan pertimbangan nilai pretest terendah yaitu kelas VIII G sebanyak 30 siswa. Hasil penelitian menunjukkan bahwa media pembelajaran Matematika SMP berbasis android berorientasi UoS dapat meningkatkan hasil belajar siswa.

Kata kunci: media pembelajaran, Android, UoS.
\end{abstract}

\section{ABSTRACT}

There are lack of students' learning resources and learning facilities available in SMP Negeri 1 Kendal. This research is intended to answer these problems. The aim of this research is to find out whether the UoS-oriented android-based mathematics learning media on circle topic can improve student learning outcomes. This is quantitative research. A purposive sampling technique is used with consideration of the lowest pretest value of class VIII $G$ as many as 30 students. The results showed that UoS-oriented android-based SMP learning media can improve student learning outcomes.

Keywords: teaching media, android, UoS. 


\section{PENDAHULUAN}

Belajar merupakan proses yang kompleks yang terjadi pada semua orang dan berlangsung seumur hidup, dimulai sejak bayi sampai ke liang lahat nanti. Proses belajar bersifat individual dan kontekstual, artinya proses belajar terjadi dalam diri peserta didik sesuai dengan perkembangan dan lingkungannya (Warsita, 2008: 62). Belajar menjadi ciri khas manusia sebagai makhluk hidup yang lebih tinggi harkatnya dibandingkan makhluk lain di muka bumi. Bagi Kemp dan Dayton (dikutip dalam Prawiradilaga 2016: 68), belajar merupakan suatu proses yang terjadi pada diri seseorang sebagai suatu pengalaman.

Proses belajar mencakup beberapa kegiatan yang beraneka ragam. Keanekaragaman jenis belajar ini muncul dalam dunia pendidikan sejalan dengan kebutuhan kehidupan pendidikan. Salah satunya adalah belajar abstrak. Menurut Syah (2010: 120), belajar abstrak ialah belajar yang menggunakan cara-cara berpikir abstrak. Tujuannya adalah untuk memperoleh pemahaman dan pemecahan masalah-masalah yang tidak nyata.

Termasuk dalam jenis belajar abstrak adalah matematika (Syah, 2010: 120). Matematika merupakan salah satu bidang studi yang ada pada semua jenjang pendidikan, mulai dari tingkat sekolah dasar sampai perguruan tinggi dan bahkan diajarkan di taman kanak-kanak secara informal. Menurut Kamus Besar Bahasa Indonesia (dikutip dalam Fathani, 2014: 22), matematika didefinisikan sebagai ilmu tentang bilangan, hubungan antar bilangan, dan prosedur operasional yang digunakan dalam penyelesaian masalah mengenai bilangan. Matematika juga merupakan ilmu yang tidak terlepas dari agama. Pandangan ini dapat diketahui kebenarannya dari ayat-ayat Al Qur'an yang berkaitan dengan matematika, salah satunya adalah ayat yang berbicara mengenai himpunan yang terdapat pada QS. Al An'am ayat 128.

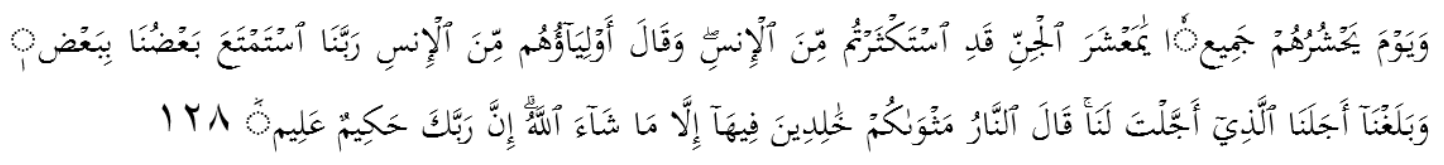

Dan (ingatlah) hari diwaktu Allah menghimpunkan mereka semuanya (dan Allah berfirman): "Hai golongan jin, Sesungguhnya kamu telah banyak menyesatkan manusia", lalu berkatalah kawankawan meraka dari golongan manusia: "Ya Tuhan kami, sesungguhnya sebahagian daripada kami telah dapat kesenangan dari sebahagian (yang lain) dan kami telah sampai kepada waktu yang telah Engkau tentukan bagi kami". Allah berfirman: "Neraka itulah tempat diam kamu, sedang kamu kekal di dalamnya, kecuali kalau Allah menghendaki (yang lain)". Sesungguhnya Tuhanmu Maha Bijaksana lagi Maha Mengetahui." (Q.S AlAn'am [6] : 128)

Diagram Venn yang digambarkan dalam ayat tersebut adalah dua himpunan yang saling lepas karena tidak memiliki irisan $(\cap)$. Himpunan semesta $S$ adalah himpunan makhluk ciptaan Allah. Himpunan A adalah golongan jin, dan himpunan B adalah golongan manusia (Huda dan Mutia, 2017: 191).

Kebutuhan akan aplikasi matematika saat ini dan masa depan tidak hanya untuk kebutuhan sehari-hari, melainkan juga untuk mendukung kemajuan perkembangan ilmu pengetahuan (Syafri, 2016: 1). Oleh karena itu, matematika sebagai ilmu dasar perlu dikuasai 
dengan baik oleh siswa. Namun pada kenyataannya bagi sebagian siswa, mata pelajaran matematika justru dianggap sebagai pelajaran yang abstrak dan membosankan. Bahkan sebagian orang Indonesia memberikan plesetan dengan menyebut matematika sebagai "matimatian" karena sulitnya mempelajari matematika (Fathani, 2014: 22). Objek matematika (termasuk geometri) yang bersifat abstrak merupakan kesulitan yang harus dihadapi oleh siswa dalam mempelajari matematika. Tidak hanya siswa, guru pun juga mengalami kendala dalam mengajarkan matematika dikarenakan sifatnya yang abstrak tersebut (Sundayana, 2014: 3).

Berdasarkan angket yang diberikan kepada 31 siswa kelas VIII SMP Negeri 1 Kendal, $74,2 \%$ siswa mengalami kesulitan dalam belajar matematika. Siswa yang mengalami kesulitan dalam belajar matematika menganggap matematika itu rumit, sulit menghafal rumus, dan terlalu banyak berhitung. Siswa yang mengalami kesulitan belajar diantaranya disebabkan faktor intelektual, diantaranya kurang berhasil dalam menguasai konsep, prinsip, atau algoritma walaupun telah berusaha mempelajarinya. Siswa mengatakan belajar matematika sulit karena sulit mengabstraksi, menggeneralisasi, berpikir deduktif, sukar mengingat konsep-konsep maupun prinsip-prinsip (Hamzah, 2014: 59). Salah satu cara yang dapat dilakukan oleh guru agar siswa mudah dalam mempelajari matematika, adalah penggunaan media belajar yang mempermudah pemahaman siswa (Pitadjeng, 2015: 64).

Gagne (dikutip dalam Neolaka, 2017: 239) menyatakan bahwa media adalah berbagai jenis komponen dalam lingkungan siswa yang dapat merangsangnya untuk belajar. Penggunaan media dalam pembelajaran memiliki peranan penting diantaranya sebagai sarana yang dapat memberikan pengalaman baru bagi siswa, mendorong motivasi belajar, memperjelas dan mempermudah konsep abstrak, serta mempertinggi daya serap siswa (Neolaka, 2017: 241).

Pertumbuhan pengguna smartphone di Indonesia terbilang tinggi. Untuk pemakai muda (18-34 tahun) kepemilikan smartphone meningkat dai 39 persen menjadi 66 persen sedangkan untuk pengguna berusia di atas 50 tahun juga naik dari 2 persen pada 2015 menjadi 13 persen pada 2018 (Tempo 2019, diakses 9 April 2019). Demikian juga di SMP Negeri 1 Kendal, berdasarkan angket analisis kebutuhan, seluruh responden siswa kelas VIII SMP Negeri 1 Kendal sebanyak 31 siswa menyatakan memiliki handphone Android. 67,7\% siswa menyatakan bahwa media berbasis android merupakan media pembelajaran yang menarik. $80,6 \%$ menyatakan perlu menggunakan media pembelajaran berbasis android dalam pembelajaran matematika. Hal ini memberikan peluang pada pengembangan media pembelajaran berbasis Android.

\section{METODOLOGI}

Jenis penelitian ini adalah penelitian kuantitatif dengan desain yang digunakan adalah eksperimen/before-after (Sugiyono, 2015: 303). Hal ini dilakukan untuk mengetahui apakah media yang ada dapat meningkatkan hasil belajar siswa. 


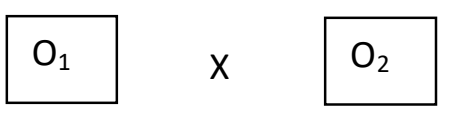

$\mathrm{O}_{1}$ adalah nilai sebelum treatment dan $\mathrm{O}_{2}$ adalah nilai sesudah treatment. Uji coba dilakukan dengan membandingkan hasil observasi $\mathrm{O}_{1}$ dan $\mathrm{O}_{2} . \mathrm{O}_{1}$ adalah hasil belajar sebelum penggunaan media, sedangkan $\mathrm{O}_{2}$ adalah hasil belajar setelah penggunaan media.

Subjek penelitian adalah benda, hal, atau orang tempat data untuk variabel penelitian melekat (Arikunto, 1990: 116). Subjek penelitian dalam penelitian ini adalah siswa kelas VIII G SMP Negeri 1 Kendal yang dipilih menggunakan teknik purposive sampling dengan pertimbangan nilai pretest terendah. Teknik pengambilan data menggunakan tes. Tes merupakan suatu teknik atau cara yang digunakan dalam rangka melaksanakan kegiatan pengukuran yang di dalamnya terdapat berbagai pertanyaan, atau serangkaian tugas yang harus dikerjakan atau dijawab oleh peserta didik untuk mengukur aspek perilaku peserta didik (Arifin, 2016: 118). Metode tes dalam penelitian ini digunakan untuk mengetahui peningkatan hasil belajar siswa setelah penggunaan media. Instrumen yang digunakan yaitu soal pretest dan posttest. Soal pretest dan posttest yang digunakan dalam penelitian ini adalah soal-soal uraian.

Tes yang digunakan terlebih dahulu dilakukan tes validasi sehingga mendapatkan instrument tes yang layak, dengan langkah seperti berikut.

\subsection{Analisis Validitas}

Untuk melihat apakah tes tersebut valid (sahih), digunakan rumus product moment sebagai berikut.

$$
r_{x y}=\frac{N \sum X Y-\left(\sum X\right)\left(\sum Y\right)}{\sqrt{\left\{\left(N \sum X^{2}-\left(\sum X\right)^{2}\right)\left(N \sum Y^{2}-\left(\sum Y\right)^{2}\right)\right\}}}
$$

Keterangan:

$r_{x y}=$ Koefisien korelasi antar variable $\mathrm{X}$ dan $\mathrm{Y}$

$N=$ Banyaknya peserta tes

$X=$ Skor butir soal

$Y=$ Skor total

Untuk mengetahui valid atau tidaknya butir soal, maka hasil perhitungan $r_{x y}$ dikorelasikan dengan $r_{\text {tabel. }}$ Jika $r_{x y}>r_{\text {tabel }}$ maka butir soal dikatakan valid, sebaliknya jika $r_{x y}<$ $r_{\text {tabel }}$ maka butir soal dikatakan tidak valid (Hamzah, 2014: 221-222).

\subsection{Analisis Reliabilitas}

Reliabilitas adalah tingkat atau derajat konsistensi dari suatu instrument. Reliabilitas tes berkenaan dengan pertanyaan, apakah suatu tes teliti dan dapat dipercaya sesuai kriteria yang telah ditetapkan (Arifin, 2016: 258). 


$$
r_{11}=\left(\frac{R}{R-1}\right)\left(1-\frac{\sum \sigma_{i}^{2}}{\sigma_{t}^{2}}\right)
$$

Keterangan:

$r_{11} \quad=$ Reliabilitas Tes Secara Keseluruhan

$\mathrm{R} \quad=$ banyak soal yang valid

$\sum \sigma_{i}^{2}=$ jumlah varians skor tiap-tipa butir soal

$\sigma_{t}^{2} \quad=$ varians skor total (Arifin, 2016: 264)

Setelah diperoleh indeks angka reliabilitas, langkah selanjutnya adalah mengonsultasikan angka tersebut dengan $r$ tabel pada taraf signifikasi 5\%. Apabila $r$ hitung lebih besar atau sama dengan $r$ tabel diartikan ada korelasi yang signifikan, instrumen dianggap reliabel. Sebaliknnya apabil $r$ hitung lebih kecil dari $r$ tabel diartikan tidak ada korelasi yang signifikan kesimpulan instrumen dianggap tidak reliabel (Widoyoko, 2010: $151)$.

\subsection{Tingkat Kesukaran}

Tingkat kesukaran soal adalah peluang untuk menjawab benar suatu soal pada tingkat kemampuan tertentu yang biasa dinyatakan dengan indeks. Semakin besar indeks tingkat kesukaran berarti soal tersebut semakin mudah (Arifin, 2016: 134).

$$
\text { Tingkat kesukaran }=\frac{\text { Rata }- \text { rata }}{\text { Skor maksimum tiap soal }}
$$

Klasifikasi:

$0,00-0,30=$ sukar,

$0,31-0,70=$ sedang,

$0,71-1,00=\operatorname{mudah}($ Arifin, 2016: 135).

\subsection{Daya Pembeda}

Daya pembeda soal adalah kemampuan suatu soal untuk membedakan antara peserta didik yang menguasai materi dengan peserta didik yang kurang menguasai materi (Arifin, 2016: 133).

$$
D P=\frac{\bar{X} K A-\bar{X} K B}{\text { Skor Maks }}
$$

Keterangan :

$\mathrm{DP}=$ daya beda

$\bar{X} K A \quad=$ rata-rata kelompok atas

$\bar{X} K B \quad=$ rata-rata kelompok bawah

Skor maks $=$ skor maksimum
Klasifikasi:

0,40 ke atas = sangat baik

$0,30-0,39=$ baik

$0,20-0,29=$ cukup, soal perlu perbaikan

$0,00-0,19=$ kurang baik, dibuang

(Arifin, 2016: 133) 
Sedangkan untuk mengetahui signifikasi peningkatan hasil belajar sebelum dan sesudah peggunaan media, perlu diuji secara statistik dengan uji t berkorelasi (related). Rumus yang digunakan sebagai berikut (Sugiyono, 2015: 307).

$$
t=\frac{\bar{X}_{1}-\bar{X}_{2}}{\sqrt{\frac{s_{1}^{2}}{n_{1}}+\frac{s_{2}^{2}}{n_{2}}-2 r\left(\frac{s_{1}}{\sqrt{n_{1}}}\right)\left(\frac{s_{2}}{\sqrt{n_{2}}}\right)}}
$$

Keterangan:

$\bar{X}_{1} \quad$ : Rata-rata sampel setelah penggunaan media

$\bar{X}_{2}$ : Rata-rata sampel sebelum penggunaan media

$s_{1} \quad$ : Simpangan baku sampel setelah penggunaan media

$s_{2} \quad$ : Simpangan baku sampel sebelum penggunaan media

$s_{1}^{2} \quad$ : Varians sampel setelah penggunaan media

$s_{2}{ }^{2} \quad$ : Varians sampel sebelum penggunaan media

$r \quad$ : Korelasi antara 2 kelompok

Hipotesis yang digunakan adalah sebagai berikut.

Ho : hasil belajar setelah penggunaan media lebih rendah atau sama dengan sebelum penggunaan media $\left(\mu_{1} \leq \mu_{2}\right)$.

Ha : hasil belajar setelah penggunaan media lebih baik dari sebelum penggunaan media $\left(\mu_{1}>\mu_{2}\right)$.

Untuk membuat keputusan, apakah perbedaan itu signifikan atau tidak, maka harga $\mathrm{t}$ hitung tersebut perlu dibandingkan dengan harga t tabel dengan $\mathrm{dk} n-2$ dengan taraf kesalahan 5\%. Bila harga $t$ hitung jatuh pada daerah penerimaan Ha, maka Ha diterima (Sugiyono, 2015: 309).

\section{PEMBAHASAN}

Hasil belajar siswa setelah penggunaan media menunjukkan peningkatan dibandingkan sebelum penggunaan media. Rata-rata hasil belajar yang dicapai sebelum penggunaan media adalah 53,8 sedangkan hasil belajar setelah penggunaan media menunjukkan rata-rata 72,3. Hasil perhitungan uji $t$ diperoleh nilai $t$ hitung $=7,446$. Hasil uji $\mathrm{t}$ menunjukkan bahwa $t$ hitung berada pada daerah penolakan $\mathrm{H}_{0}$, maka dapat disimpulkan bahwa peningkatan hasil belajar siswa adalah signifikan. Peningkatan hasil belajar ini sejalan dengan penelitian yang dilakukan oleh Muyasaroh dan Fajartia (2017) yang menunjukkan bahwa penggunaan media berbasis android dapat meningkatkan hasil belajar siswa.

Hasil belajar siswa meningkat dikarenakan pembelajaran dengan menggunakan media ini dapat memotivasi siswa dalam belajar. Media ini dikemas dalam bentuk aplikasi dengan tampilan yang menarik dari segi tampilan,warna, gambar dan animasi sehingga membuat siswa lebih senang dalam belajar. Sebagaimana menurut Zaniyati (2017: 33), siswa akan belajar manakala mereka memiliki motivasi yang kuat dalam belajar. Media yang menarik 
juga turut serta mendorong siswa dalam mempelajari materi dengan baik. Selain itu, dalam setiap subbab dalam media dilengkapi dengan ilustrasi yang berupa gambar dan animasi sehingga mampu memvisualisasikan objek lingkaran yang bersifat abstrak. Menurut Utami (2011: 45), animasi memiliki dua peran yaitu untuk menarik perhatian siswa dan memperkuat motivasi serta sebagai sarana untuk memberikan pemahaman kepada murid atas materi yang diberikan. Sehingga adanya animasi dalam media ini dapat mempermudah siswa dalam memahami materi lingkaran. Hal tersebut juga sesuai dengan pendapat Mayer dan Moreno (2002: 93) yang mengatakan:

Students learn more deeply from animation and narration than from narration alone. Students are better able to build mental connections between corresponding words and pictures when both are presented (i.e., animation and narration) than when only one is presented (i.e., narration).

Siswa akan lebih mudah memahami ketika disajikan animasi dan narasi daripada membaca narasi saja. Hal ini dikarenakan siswa lebih mampu membangun hubungan mental antara kata dan gambar daripada hanya disajikan narasi. Menurut Zaniyati (2017: 182), salah satu keuntungan penggunaan animasi adalah menjadikan media lebih menarik, tidak membosankan, dan dapat menambah motivasi belajar. Animasi yang terdapat dalam media ini diantaranya animasi mengenai konsep luas lingkaran dengan pendekatan luas persegi panjang serta animasi konsep keliling lingkaran dan cara menemukan phi $(\pi)$.

Selain itu media yang dikembangkan juga memuat soal-soal latihan yang berupa soal pilihan ganda. Setiap soal latihan disertai umpan balik terhadap setiap jawaban yang dipilih siswa. Setiap umpan balik yang diberikan juga memuat pembahasan sehingga dapat digunakan sebagai bahan belajar siswa. Menurut Prawiladilaga dan Siregar (2004: 20) hasil belajar akan meningkat jika diberi umpan balik. Secara teknis umpan balik diberikan dalam bentuk kunci jawaban yang benar. Bedasarkan uraian tersebut dapat disimpulkan bahwa penggunaan media ini dalam pembelajaran dapat meningkatkan hasil belajar siswa.

\section{DAFTAR PUSTAKA}

Arifin, Z. 2016. Evaluasi Pembelajaran. Bandung: Remaja Rosdakarya.

Arikunto, S. 1990. Manajemen Penelitian. Jakarta: Rineka Cipta.

Bustomi, A.Y. 2010. Aplikasi Pembelajaran Panca Indera Manusia Berbasis Android. Jurnal Telematika. 3(1).

Fathani, A.H. 2014. Matematika Hakikat dan Logika. Yogyakarta: Ar-Ruzz Media

Fatimah, S. dan Mufti, Y. Pengembangan Media Pembelajaran IPA-Fisika Smartphone Berbasis Android Sebagai Penguat Karakter Sains Siswa. Jurnal Kaunia. 10(1).

Hamzah, A. 2014. Evaluasi Pembelajaran Matematika. Depok: Rajagrafindo Persada

Alfarizi, M.K. 2019. Survei Kepemilikan Smartphone, Indonesia Peringkat ke-24. Diakses di https://tempo.co/read/1181645/survei-kepemilikan-smartphone-indonesia-peringkat-ke24 tanggal 9 April 2019

Kustandi, C. dan Sutjipto, B. 2013. Media Pembelajaran. Bogor: Penerbit Ghalia Indonesia. 
Lubis, I.R. dan Ikhsan, J. 2015. Pengembangan Media Pembelajaran Kimia Berbasis Android Untuk Meningkatkan Motivasi Belajar dan Prestasi Kognitif Peserta Didik SMA. Jurnal Inovasi Pendidikan IPA. 1(2).

Mayer, R.E dan Moreno, R. 2002. Animation as an Aid to Multimedia Learning. Educational Psychology Review. 14(1).

Neolaka, A. dan Neolaka, G.A.A. 2017. Landasan Pendidikan: Dasar Pengenalan Diri Sendiri Menuju Perubahan Hidup. Jakarta: Kencana.

Pitadjeng. Pembelajaran Matematika yang Menyenangkan. Yoyakarta: Graha Ilmu.

Prawiradilaga, D.S. 2016. Wawasan Teknologi Pendidikan. Jakarta: Prenadamedia Group.

Rusuli, I dan Fuady, Z. Ilmu Pengetahuan Dari John Locke ke Al-Attas. Junal Pencerahan 9(1): 14 .

Setyosari, P. 2016. Metode Penelitian Pendidikan dan Pengembangan. Jaakarta: Prenadamedia Group.

Sugiyono. 2015. Metode Penelitian Kuantitatif, Kualitatif, dan $R \& D$. Bandung: Alfabeta.

Sukmadinata, N.S. 2011. Metode Penelitian Pendidikan. Bandung: Remaja Rosdakarya.

Sundayana, R. 2014. Statistika Penelitian Pendidikan. Bandung: Alfabeta.

Supena, I. 2014. Paradima Unity of Science IAIN Walisongo Dalam Tinjauan Filsafat Ilmu. Laporan Penelitian Individu. Semarang: IAIN Walisongo Semarang.

Syafri, F.S. Pembelajaran Matematika. Yogyakarta: Matematika.

Syah, M. 2010. Psikologi Pendidikan. Bandung: Remaja Rosydakarya Offset.

Warsita, B. 2008. Teknologi Pembelajaran. Jakarta: Rineka Cipta.

Widoyoko, E.P. 2014. Penilaian Hasil Pembelajaran di Sekolah. Yogyakarta: Pustaka Pelajar. 